\title{
5. Sınıf Matematik Ders Kitabının Değerlerimiz Açısından İncelenmesi
}

\author{
Doktora Öğrencisi Volkan Sayın ${ }^{1 *}$ \\ Prof. Dr. Keziban Orbay ${ }^{2}$ \\ Prof. Dr. Emine Altunay Şam ${ }^{3}$
}

Geliş tarihi: 10.08.2019

Kabul tarihi: 09.09.2019

\section{Atıf bilgisi:}

IBAD Sosyal Bilimler Dergisi

Sayı: Özel Sayı Sayfa: $161-171$

Yıl: 2019

This article was checked by iThenticate. Similarity Index $11 \%$.

\author{
1Amasya Universitesi, Türkiye, \\ volkan.sayin@hotmail.com, \\ ORCID ID 0000-0002-7365-0050 \\ 2Amasya Üniversite, Türkiye, \\ keziban.orbay@amasya.edu.tr, \\ ORCID ID 0000-0002-7642-4139 \\ ${ }^{3}$ Amasya Üniversitesi, Türkiye, \\ emine.sam@,hotmail.com
}

ORCID ID 0000-0003-2140-3450

* Sorumlu yazar
ÖZ

Bir toplumun varlığını sürdürebilmesi için temel değerleri cocuklarına aşılaması gerekir. Bu aşılama okullarda ders ortamında öğretmen eşliğinde olabileceği gibi çocuğun okul dıșı çalışma ortamında kendisinin bile farkında olmadan kitabıyla çalışırken bilinçaltında gerçekleşebilir. Dolayısıyla ders kitaplarında yer alan değerler önem kazanmaktadır. Bu araştırmada ortaokul 5. Sınıf matematik ders kitabının matematik öğretimi programında yer alan değerler açısından incelenmesi amaçlanmıştır. $\mathrm{Bu}$ değerler adalet, dostluk, dürüstlük, öz denetim, sabır, saygı, sevgi, sorumluluk, vatanseverlik ve yardımseverliktir. Araştırmada nitel araştırma yöntemi benimsenip doküman incelemesi ile veriler toplanmıştır. Verilerin çözümlenmesinde betimsel analiz tekniği kullanılmıştır. Elde edilen sonuçlara göre en çok değinilen değerler öz denetim, adalet, yardımseverlik ve sorumluluk değerleri olup en az değinilen değerler ise dostluk, dürüstlük, vatanseverlik, saygı ve sevgi değerleridir. Ünitelere göre değerlerin dağılımında düzensizlik olduğu görülmüş ve betimsel analizler örneklerle birlikte ayrıntılı bir şekilde verilmiştir.

Anahtar Kelimeler: Matematik, Ders Kitab1, Değerler. 


\title{
Research of $5^{\text {th }}$ Grade Mathematics Textbook in terms of Our Values
}

\author{
Doctoral Student Volkan Sayın ${ }^{1^{*}}$ \\ Prof. Dr. Keziban Orbay \\ Prof. Dr. Emine Altunay Şam ${ }^{3}$
}

First received: 10.08 .2019

Accepted: 09.09.2019

\section{Citation:}

IBAD Journal of Social Sciences

Issue: Special Issue Pages: 161-171

Year: 2019

This article was checked by iThenticate. Similarity Index $11 \%$.

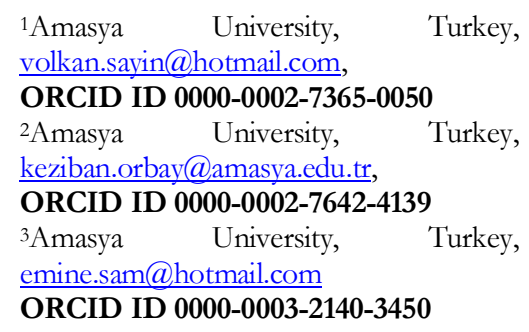

* Corresponding Author

\begin{abstract}
In order for a community to continue one's existence, it is necessary to instill the basic values to its children. This instillation can be accompanied by a teacher in a school environment, or in a child's out-of-school working environment, even unconsciously while working with a book. Therefore, the values in the textbooks gain importance. In this research, it is aimed to examine the 5th grade mathematics textbook in terms of values in mathematics teaching program. These values are justice, friendship, honesty, self-control, patience, respect, love, responsibility, patriotism and helpfulness. Qualitative research method was adopted in the study and data were collected by document analysis. Descriptive analysis technique was used to analyze the data. According to the results, the most frequently mentioned values are self-control, fairness, helpfulness and responsibility, and the least mentioned are values of friendship, honesty, patriotism, respect and love. The distribution of values according to the units was found to be irregular and descriptive analyzes were given in detail with examples.
\end{abstract}

Keywords: : Mathematics, textbook, values. 


\section{GİRIŞ}

Günlük hayatta karşılaşılan sorunların üstesinden gelebilmek için gereken güç ve kudretin kaynağı olan değerlerimiz her ne kadar kökünü geçmişten alsa da günümüzden beslenip geleceğe de uzanmaktadır. Bir toplumun ileriye taşınabilmesi için bireylerin yetkin ve değerler eğitimiyle yoğrulmuş olması gerekmektedir. Eğitim sisteminde sadece akademik açıdan başarılı belli bilgi ve becerileri kazanan bireyler yetişmektedir. Bununla birlikte toplumun temel değerlerini özümsemiş bireylerin yetişmesi hedeflenmektedir. Hedeflere ulaşma yolunda öğretim programları, eğitim materyalleri, ders dışı çalışmalar, kanun, yönetmelik gibi eğitim sisteminin unsurları bir bütün halinde düşünülmelidir. Değerlerimiz belli bir ünite veya belli bir konu olarak görülmeyip öğretim programlarının içine genel olarak konulmuştur (Milli Eğitim Bakanlığı [MEB], 2018).

Değerler eğitiminde temel nokta ahlaklı ve kişilik sahibi bireyler yetiştirmektir. Bu değerler ailenin yanı sıra okul, çevre, medya ve sosyal medya gibi unsurlarla birlikte kişiye kazandırılabilir. Okullarda toplumsal değerler ifade edilirken ders kitaplarının önemi ortaya çıkmaktadır (Deniz ve Karagöl, 2018, s. 246). Öğretim programlarının uygulanmasında önemli bir unsur olan ders kitaplarının değerler eğitimi açısından da yeterli olması gerekmektedir. Toplumu oluşturan bireylerin üzerinde uzlaştıkları düşünce, amaç ve temel ahlaki ilkeler değerlidir. Bu değerler toplumun var olması ve devamının sağlanması bakımından genel olarak kabul gören unsurlardır (Özgüven, 1999, s. 367-368).

Eğitimciler arasında tartışma konusu olan eğitimin amacını oluşturan üç önemli nokta vardır. İnsanın zihinsel faaliyetler ile düşünme becerisinin gelişimi, duygu ve irade açısından gelişim ile bedenin eğitilmesi olarak ifade edilebilir. Başarılı bireylerin kendilerine verilen sorumlulukları başarıyla üstesinden gelebilmesi için zihinsel yeteneklerini geliştirip, bedenini eğitip ruhunu da besleyerek olumlu değerlerle donatması gerekmektedir (Meydan, 2014, s. 93).

Eğitimin amacına ulaşmasında okullar önemli bir etkiye sahip olmalıdır. Bu etki nesillerin alışkanlıklarını, değerlerini ve sosyal davranışlarını yönlendirebilecek nitelikte olmalıdır. Değişen dünyada karşılaşılan sorunlara çözüm önerileri üretebilmelidir (Ekşi, 2003, s. 79).

Kültürün bir parçası olmakla beraber kültürün kıymetini ortaya koymada bir ölçüt (Silah, 2000, s. 72) olan değerler toplumsal mirasın standart olmuş halidir. Bireyler bu standart durumlara göre davranışlarının sınırlarını çizer (Şen, 2007, s. 5). Değerler davranışlarımıza rehberlik yapmanın yanı sıra karşımızdaki diğer bireylerin davranışlarını da etkiler. Toplum içerisinde birbirleriyle iletişim halinde bulunan bireyler davranışlarının hangilerinin genel geçer olduğunu veya olmadığını toplumun önceden oluşmuş yerleşik farklı değerlere göre belirler (Beil, 2003, s. 14).

Gün geçtikçe teknolojik gelişmenin etkisiyle hızla değişen dünyada bireylerin değerlerini, kişiliklerini muhafaza etmesinin zorluğu bilinmektedir. Teknolojideki buluşlar, araç-gereçler toplumda amaç dışı kullanılarak kültürel ve sosyolojik farklılıklar oluşmasını sağlayarak bozulmalara sebep olmaktadır (Elbir ve Bağc1, 2013, s. 1322). Bu bozulmalar sosyal medyada birbirini tanımayan insanların duygu ve düşüncelerinden dolayı birbirine hakaret etmesi, küfürlü ifadelerde bulunmaları, uygunsuz teklifte bulunmaları, taciz, iftira, yalanlarla kişilerin itibarlarını küçük düşürücü davranışlarda bulunmaları şeklinde örneklendirilebilir.

Toplum hayatının düzenlenip olumsuzlukların ortadan kaldırılması değerler eğitimi ile mümkün olabilecektir. Değerler eğitimi aile ile başlayıp okul ile devam eden ve hayat boyu devam edecek dinamik bir süreçtir. Bu süreç toplum yaşantısında önceden doğru bilinen yanlışların ortadan kaldırılarak veya yeni ortaya konan kültürel parçaların ortaya konması ile oluşan yenilenme durumu olarak görülebilir. Fakat bu süreç çok kısa sürede gerçekleşebilecek bir durum değildir.

Bireylerin değerleri özümseyip kişilik haline getirerek davranış biçimine dönüştürme amacıyla ömür boyu devam eden eğitim, değerler eğitimi olarak ifade edilir (Yaman, 2012, s. 17). Değerler eğitiminin temel amacı bilinçli olarak kişinin kendini tanıyıp anlayarak gerçekleştirmesidir (Keskin, 2008, s. 20). 
Aile, bireylerin iletişim halinde olduğu ortam ve eğitim kurumları değerlerin kazandırılmasında önem taşır. Birey, kendi bilişsel ve duyuşsal davranışlarının sorumluluklarını alabilene kadar aile değerlerine bağlı bir hayat yaşar. Eğitim hayatının başlamasıyla ailenin değerlerine ek olarak okulda verilen değerlerle iç içe geçen yeni bir oluşum başlar (Çınar, 2013, s. 193).

Okullarda değerler eğitimi öğretim programları aracılığı ile gerçekleşmektedir. Bundan dolayı öğretim programları değerlerin öğrencilere kazandırılması noktasında önem taşımaktadır (Kardaş ve Cemal, 2017, s. 384). Okullarda öğrenciler zamanının büyük kısmında ders kitabı kullanmaktadırlar. Öğrencilerin kaynak olarak kullanıp takip ettikleri ders kitapları aynı zamanda temel değerlerin kazandırılmasında kullanılan genel bir araç-gereçtir (Çelikkaya ve Kürümlüoğlu, 2018, s. 10).

Ders kitapları ilgili dersin öğretim programıyla uyumlu olmakla beraber belli bir seviyedeki öğrenciye hitap ederek öğrenmeyi sistemli bir şekilde sağlamak için düzenlenmiş kitaplardır (Güneş, 2002, s. 34). Ders kitapları öğrenci ve öğretmen için eğitim öğretim sürecinde yol göstericidir. İlgili alanda sistemli olarak bilgiyi aktarmanın yanında toplum olarak ortak görülen değerleri, davranış ve düşünce tarzlarını aktaran bir araçtır (Tanrı̈̈ver, 2003, s. 110).

Değerler eğitimi sürecinde iki farklı sorunla karşı karşıya gelinmektedir. Bunlardan birincisi okullarda ortak değerlerin belirlenip eğitim-öğretim sürecinde tutarlılık sağlamada karşımıza çıkmaktadır. Değerlerin çok fazla çeşidi olduğu düşünüldüğ̈̈nde okullarda öğretimine vurgu yapılacak değerlerin tespiti önem taşır. İkinci sorun ise okullarda öğretilen değerlerle okul dışında kişilerin karşılaştığı değerler arasında uyuşmanın olmayışı olarak ortaya çıkmaktadır (Halstead ve Taylor 1996, s. 11-12).

2018 yılında Milli Eğitim Bakanlığı tarafindan yayınlanan matematik öğretim programında değerler başlı̆̆ı ayrıca yer almıştır. Bu başlığın altında kök değerler adı altında on temel değere yer verilmiştir (MEB, 2018). Değerlerin öğretim programında yer alması ülke genelinde değerler eğitimi konusunda tutarlılık sağlayacaktır.

Değerlerle ilgili olarak farklı sınıflandırmalar yapılmıştır. Örneğin Spranger (2001, s. 61-62) değerleri bilimsel, ekonomik, sosyal, politik, dini ve estetik olarak altı grupta ele almıştır. Schwartz (2012, s. 3-7) değerleri; öz-yönetim, başarı, hazc1lık-zevk, güç-uyma, güvenlik, geleneksellik, harekete geçme, yardımseverlik, evrenselcilik şeklinde ifade etmiştir. Nelson (1987) ise değerleri bireysel, grup ve sosyal değerler olarak üçe ayırmıştır.

Değerler eğitimindeki gaye değerler arasında birliktelik sağlayıp bir ahenk içinde sevgi, saygı, sorumluluk, hoşgörü, adalet gibi değerlerin kazandırılmasıdır. Edinilen bu değerler olgu ve olayları karşılaştırmada kıyas aracı olarak kişide yer bulacaktır (Kıncal, 2007, s. 26).

Matematik eğitiminde değerler eğitimi yeterince önemsenmese de matematik alanında da değerlerin yer alabileceği ifade edilmiştir (Dede, 2007, s. 13). Ortaokul matematik ders kitaplarının değerler eğitimi açısından incelenmesi ile ilgili literatür incelendiğinde Şahin ve Başgül (2018)'ün çalışmasına rastlanılmıştır. Bunun dışında ders kitaplarını değerler eğitimi açısından ele alan araştırmaların Türkçe, sosyal bilgiler ve hayat bilgisi kitaplarında yoğunlaştıkları görülmüş̧ür (Baki, 2019; Deniz ve Karagöl, 2018; Şahin ve Ersoy, 2012; Güzel Candan ve Ergen, 2014; Kuş, Merey ve Karatekin, 2013). Bu araştırma önceki yapılan çalışmayla karşılaştırma imkânı da sunacak ve matematik ders kitabının değerler eğitimi açısından durumunun tutarlı olup olmadığı görülebilecektir. Değerlerin öğretim programlarında yer alması ile birlikte ders kitaplarının değerler eğitimine katkıda bulunacak nitelikte olmasının gerekliliği ortaya çıkmıştır. 2018-2019 eğitim öğretim yılında okutulan ortaokul 5.sınıf matematik ders kitabı incelenmesi, hangi değerlere ne derecede değinildiğini ortaya koyması açısından önem taşımaktadır. Bu bağlamda, ortaokul 5.sınıf matematik ders kitabının matematik öğretimi programında yer alan kök değerlere göre incelenmesi amaçlanmıştır.

\section{YÖNTEM}

\subsection{Araștırmanın Modeli}

$\mathrm{Bu}$ araştırmada nitel araştırma yöntemlerinden biri olan durum çalışması kullanılmıştır. Durum çalışması tek bir olayın, tek bir dokümanın veya bir olayın detaylı bir şekilde incelenmesi 
olarak belirtilmiştir (Bogdan ve Biklen, 1992, s. 6-7). Veri toplama yöntemi olarak doküman incelemesi kullanılmıştır. Doküman analizi hedeflenen olgu ve olguları içeren yazılı materyallerin incelenmesi anlamına gelmektedir (Yıldırım ve Şimşek, 2011, s. 187). Eğitim araştırmalarında ders kitapları, program, öğrenci kayıtları, öğretmen el kitapları, ders planları vb. dokümanlar veri kaynağı olarak kullanılabilir (Bogdan ve Biklen, 1992, s.6-7).

Araştırmada 2018-2019 eğitim öğretim yılında Milli Eğitim Bakanlığına bağlı devlet okullarında okutulan Cırıtcı, H., Gönen, İ., Kavas, D., Özarslan M., Pekcan, N. ve Şahin, M. (2017) tarafından kaleme alınan 5.sınıf ortaokul matematik ders kitabı incelenmiştir.

\subsection{Verilerin Analizi}

Araştırmada elde edilen veriler betimsel analiz yaklaşımı ile çözümlenmiştir. Daha önceden belirlenmiş temalara göre veriler özetlenip yorumlanır. Temalara göre oluşturulan kavramsal çerçeve içerisinde verilerin hangi temalar altında bir araya getirileceğine dikkat edilmesi gerekir. Anlamlı ve mantıklı bir tanımlama sürecinden sonra sonuçların yazılma aşamasında doğrudan alıntılara da yer verilir (Yıldırım ve Şimşek, 2011, s. 224).

Araştırmada tema olarak değerler eğitimi açısından 2018 yılında yayınlanan matematik öğretimi programında yer alan kök değerler dikkate alınmıştır. Programda yer alan kök değerler adalet, dostluk, dürüstlük, öz denetim, sabır, saygı, sevgi, sorumluluk, vatanseverlik ve yardımseverliktir. Bu temel değerlerin altında veriler tanımlanmıştır. Tanımlanan verileri desteklemek amacıyla doğrudan alıntılara yer verilmiştir.

\subsection{Geçerlilik ve Güvenirlilik}

Nitel araştırmalarda geçerlilik araştırılan olgunun veya olayın olduğu gibi tarafsız bir şekilde ortaya konması ile gerçekleşir (Kirk, Miller ve Miller, 1986, s.30). Araştırmada elde edilen veriler literatür taraması neticesinde değerlendirilerek ortaya çıkan sonuçların teyidi sağlanmıştır. Araştırmada temel değerlerin değinildiği yer olarak görülen kitaptaki bazı kısımlar olduğu gibi alıntılanarak geçerlilik arttırılmaya çalışılmıştır. Ayrıca kriter olarak belirlenen kök değerlerimizi çağrıştıran anahtar kelimeler kullanılarak kök değerler altında veriler sınıflandırılmıştır. Yapılan bu sınıflandırma araştırma sonuçlarının doğruluğunu sağlamada önemli bir etken olmuştur.

Güvenirliği sağlamak için araştırmacılar kodlamaları temel değerlere göre oluşturulan kavramsal çerçeveye göre birbirlerinden bağımsız olarak yapmışlardır. Dostluk ve vatanseverlikle ilgili iki değerin kodlanmasında görüş ayrılığına düşülmüsştür. Görüş ayrılığına düşülen değerler tekrar birlikte incelenmiştir. Ortak bir karara varılamadığından bu iki kod kodlar arasından çıkarılmıştır. Kodlayıcılar arası güvenirlik uzlaşılan kodların tüm kodlara oranıyla bulunur. Bu oranın \% 70'ten fazla olması beklenmektedir (Miles ve Huberman, 1994, s. 278). Araştırmacılar tarafindan belirtilen tüm kod sayısı kırk iken üzerinde anlaşılan kod sayısı otuz sekizdir. Buna göre araştırmada kodlayıcılar arası güvenirlik oranının $\% 95$ olduğu görülmüştür.

\section{BULGULAR}

Bu bölümde 5.sınıf matematik ders kitabı matematik öğretimi programında yer alan kök değerlere göre değerler eğitimi açısından incelenerek aşağıdaki Tablo 1 hazırlanmıştır. Tabloda ders kitabındaki değerlerin görülme sıklığı ünitelere göre yer verilmiştir.

Tablo 1: 5.Snıf Matematik Ders Kitabındaki Değerlerin Görülme Sıklığı

\begin{tabular}{lccccc}
\hline Değerler & 1.Ünite & 2.Ünite & 3.Ünite & 4.Ünite & Toplam \\
\hline Adalet & 5 & 1 & 1 & & 7 \\
\hline Dostluk & 1 & & & & 1 \\
\hline
\end{tabular}




\begin{tabular}{|c|c|c|c|c|c|}
\hline Dürüstlük & 1 & & & & 1 \\
\hline Öz Denetim & 5 & 2 & 2 & 3 & 12 \\
\hline \multicolumn{6}{|l|}{ Sabır } \\
\hline Saygı & 2 & & & & 2 \\
\hline Sevgi & 2 & 1 & & & 3 \\
\hline Sorumluluk & 3 & & 1 & & 4 \\
\hline Vatanseverlik & & 1 & & 1 & 2 \\
\hline Yardımseverlik & 4 & 1 & 1 & & 6 \\
\hline TOPLAM & 23 & 6 & 5 & 4 & 38 \\
\hline
\end{tabular}

Tablo 1' e göre 5.sınıf matematik ders kitabında adalet değerine yedi (7) kez, dostluk değerine bir (1) kez, dürüstlük değerine bir (1) kez, öz denetim değerine on iki (12) kez, sayg1 değerine iki (2) kez, sevgi değerine üç (3) kez, sorumluluk değerine dört (4) kez, vatanseverlik değerine iki (2) kez ve yardımseverlik değerine altı (6) kez yer verilirken, sabır değerine ise hiç değinilmemiştir.

1. Ünitede (Doğal Sayılar, Doğal Sayılarla işlemler, Kesirler) en fazla adalet ve öz denetim değerlerine yer verildiği görülmüştür. Sabır ve vatanseverlik değerlerine ise yer verilmemiştir. 2.Ünitede (Kesirlerle İşlemler, Ondalık Gösterim, Yüzdeler) en fazla öz denetim değerine yer verilirken dürüstlük, dostluk, sabır, saygı ve sorumluluk değerlerine yer verilmemiştir. 3. Ünitede (Temel Geometrik Kavramlar ve Çizimler, Üçgenler ve Dörtgenler, Veri İşleme) en fazla öz denetim değeri yer alırken dostluk, dürüstlük, sabır, saygı, sevgi ve vatanseverlik değerlerine yer verilmemiştir. 4. Ünitede (Uzunluk ve Zaman Ölçme, Alan Ölçme, Geometrik Cisimler) en fazla öz denetim değerine yer verilirken vatanseverlik değerine de bir kere yer verilmiştir. Bu iki değer dışında diğer değerlere değinilmemiştir.

Ders kitabındaki üniteler genel olarak bakıldığında en fazla değer 1. Ünitede yer bulurken, en az değer de 4. Ünitede yer almıştır. 1. Ünitede yirmi üç (23) değere, 2. Ünitede altı (6) değere, 3.Ünitede beş (5) değere ve 4.Ünitede dört (4) değere yer verilmiştir. Kitap genelinde toplam otuz sekiz (38) kez temel değerlere değinildiği görülmüştür.

Ders kitabında ele alınan kök değerlerin kullanımlarına aşağıda örnekler verilmiştir. Bu kök değerlere kitabın hangi bölümlerinde ne şekilde yer verildiği örnekler üzerinde incelenmiştir.

\subsection{Adalet (adil olma, eșit davranma, paylașma, ...)}

\section{Birlikte Yapalım 12}

Pikniğe giden 2 aile, 11 tane ekmeği eşit şekilde paylaşacaklardır. Her aileye kaç ekmek düşeceğini bulalım.

Şekil 1. Ders kitabından adalet değerini yansıtan alıntı

Şekil 1' de 1. ünitede yer alan doğal sayılarla bölme işlemi konusundaki birlikte yapalım etkinliğinde eşit şekilde paylaşım vurgulanarak adalet değerine yer verilmiştir. 
3.2. Dostluk (diğerkâmlık, güven duyma, anlayıșıı olma, dayanıșma, sadık olma, vefalı olma, yardımlașma, ...)

6) Murat maaşının $\frac{3}{11}$ 'ünü arkadaşına borç vermiştir. Borç verdiği miktar 900 lira olduğuna göre Murat'ın maaşı kaç liradır?

Şekil 2. Ders kitabından dostluk değerini yansıtan alıntı

Şekil 2' de 1. ünitedeki kesirlerle hesaplamalar konusuna ait değerlendirme sorusunda kişinin arkadaşına borç vermesi yardımlaşma olarak ele alındığında dostluk değerine yer verildiği ifade edilebilir. Aynı zamanda borç verme ifadesi düşünüldüğünde yardımseverlik değerine de değinilmiştir.

3.3. Dürüstlük (açı ve anlașlır olma, doğru sözlü olma, güvenilir olma, sözünde durma, ...) Zihinden Toplama ve Çıkarma Iş/emleri

\section{Hızlı Toplama}

Bir mağazadan alışveriş yapan İbrahim yanda verilen ürünlerden satın almıştır. Kasada ödeyeceği miktarın 120 lira olduğunu öğrenen İbrahim aldığı ürünlerin fiyatlarını zihninden hesaplayarak tutarın yanlış olduğunu söylemiştir.
Tablo: Ürünler ve Fiyatlan

\begin{tabular}{|l|r|}
\hline Ürünler & Fiyatlar \\
\hline Gömlek & 28 lira \\
\hline Pantolon & 45 lira \\
\hline Ayakkabı & 42 lira \\
\hline
\end{tabular}

Şekil 3. Ders kitabından dürüstlük değerini yansıtan alıntı

Şekil 3'te 1.ünitede yer alan zihinden toplama ve çıkarma işlemleri konusunun başında verilen ilgi çekici örnekte yapılan yanlış hesaplamanın farkına varılarak dürüst bir şekilde ödenmesi gereken tutara dikkat çekilerek dürüstlük değerine yer verilmiştir.

\section{4. Özdenetim (davranışlarını kontrol etme, davranıslarının sorumluluğunu üstlenme, öz} güven sahibi olma, gerektiğinde özür dileme, ...)

\section{Birlikte Yapalım 3}

Illknur yeni aldığı kumbarasına birinci hafta 37 lira, ikinci hafta 25 lira, üçüncü hafta 53 lira atıyor. İlknur'un bu üç haftada kumbarasında kaç lira biriktirdiğini zihinden hesaplayalım.

Şekil 4. Ders kitabından öz denetim değerini yansıtan alıntı

Şekil 4' te 1. ünitede yer alan zihinden toplama ve çıkarma işlemleri konusundaki birlikte yapalım etkinliğinde, para biriktirmeye değinilerek tutumluluk konusu ön plana çıkartılmıştır. Burada kişinin kendi davranışlarını kontrol edip para biriktirmesiyle öz denetim değerine vurgu yapılmıştır.

\subsection{Savgı (alcakgönüllü olma, baskalarına kendine davranılmasını istediği sekilde davranma, diğer insanların kişiliklerine değer verme, muhatabının konumunu, özelliklerini ve durumunu gözetme, ...)}

\section{Birlikte Yapalım 1}

Bilge bayram ziyareti için önce Bursa'dan Iğdır'a, Iğdır'dan da Sivas'a gidecektir. Bursa - Iğdır arası 1530 kilometre, Sivas - Iğdır arası 729 kilometre olduğuna göre Bilge'nin Bursa'dan Sivas'a yaklaşık kaç kilometre yol gideceğini tahmin edelim. Tahminimizi gerçek sonuçla karşılaştıralım.

Şekil 5. Ders kitabından saygı değerini yansıtan alıntı

Şekil 5'te 1.ünitede yer alan doğal sayılarla toplama ve çıkarma işlemleri konusundaki birlikte yapalım etkinliğinde, Bilge'nin bayram ziyareti için gideceği yolun hesaplanmasında insanların kişiliklerine değer verme duygusuyla birlikte bayram ziyaretine değinildiği düşünülmüştür. Bayram ziyaretleri sevilen, sayılan ve önemsenen insanlara ziyaret olarak düşünüldüğünde saygı ve sevgi değerlerinin ikisine de değinilmiştir. 
3.6. Sevgi (aile birliğine önem verme, fedakârlık yapma, güven duyma, merhametli olma...)

\section{Birlikte Yapalım 2}

Merve annesi için yaptırdığı bir buket çiçeğe 15 lira 75 kuruş, kardeşi için aldığı çikolataya 2 lira 49 kuruş ödemiştir. Merve'nin annesi ve kardeşi için toplam kaç lira harcama yaptığını bulalım.

Şekil 6. Ders kitabından sevgi değerini yansıtan alıntı

Şekil 6'da 2. ünitede yer alan ondalık gösterimlerle toplama ve çıkarma işlemleri konusundaki birlikte yapalım etkinliğinde, anne ve kardeş için çiçek ve çikolata alınması kişinin aile kavramına önem verdiğini göstermektedir. Bundan dolayı burada sevgi değerine yer verildiği ifade edilebilir.

3.7. Sorumluluk (kendine, cevresine, vatanına, ailesine karsı sorumlu olma, sözünde durma, tutarlı ve güvenilir olma, davranıșlarının sonuçlarını üstlenme, ...)

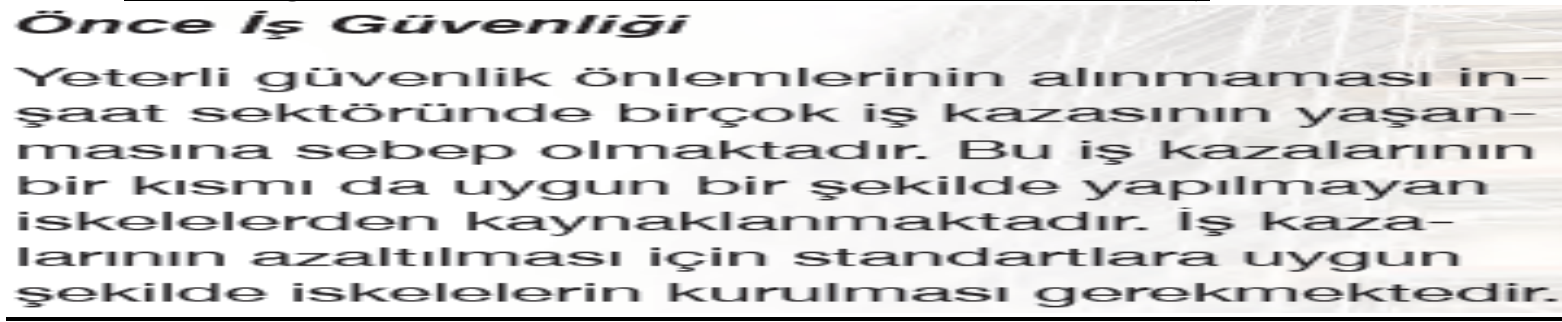

Şekil 7. Ders kitabından sorumluluk değerini yansıtan alıntı

Şekil 7'de 3. ünitedeki doğruya dik çizme konusunun girişinde öğrencinin ilgisini çekecek iş kazalarının sebepleri üzerinde durulmuştur. İş güvenliğinde sorumlu kişilerin görevini yerine getirmemesinden dolayı iş kazalarının olduğu ifade edilebilir. Böylece sorumluluk değerine yer verildiği görülebilir.

3.8. Vatanseverlik (calıskan olma, davanısma, kurallara ve kanunlara uvma, sadık olma, tarihsel ve doğal mirasa duyarlı olma, toplumu önemseme, ...) Uçak Mekaniği

Türkiye Cumhuriyeti'nin en köklü kuruluşlarından olan Türk Hava Kurumu, 1925 yılında kurulmuştur. Yandaki tabloda Türk Hava Kurumu tarafından 84 lisansıı üretimi yapılmış Maggie 14 (Megi 14) adı motorlu uçağa ait bilgiler yer almaktadır.

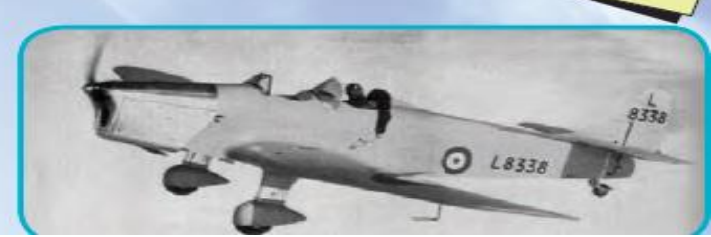

Şekil 8. Ders kitabından vatanseverlik değerini yansıtan alıntı

Şekil 8' de 2.ünitede yer alan ondalık gösterimler konusunun girişinde öğrencinin konuya ilgisini sağlamak için verilen metinde ülkemiz için toplumun menfaatleri doğrultusunda üretilen uçaklardan bahsedilmiştir. Böylece ülkemiz için çalışmanın önemi ifade edilerek vatanseverlik değerine yer verildiği söylenebilir.

3.9. Yardımseverlik (cömert olma, iș birliği yapma, merhametli olma, misafirperver olma, ...)

\section{Birlikte Yapalım 4}

Bir yardım toplama kampanyası sonucu toplanan yardımlar, her birinin içinde 346 ürün bulunan 872 adet paket yapılarak ihtiyaç sahiplerine ulaştııımıştır. Bu kampanya ile kaç adet ürününün ihtiyaç sahiplerine ulaştıııldığını bulalım.

Şekil 9. Ders kitabından yardımseverlik değerini yansıtan alıntı

Şekil 9'da 1.ünitede yer alan doğal sayılarla çarpma işlemi konusundaki birlikte yapalım etkinliğinde yardım toplama kampanyasına yer verilerek yardımseverlik değerine değinilmiştir. 


\section{TARTIŞMA VE SONUÇ}

Araștırma sonucuna göre beșinci sınıf matematik ders kitabında en fazla değere 1. Ünitede (Doğal Sayılar, Doğal Sayılarla işlemler, Kesirler) yer verilmiştir. Daha sonra fazladan aza doğru sırasıyla 2.Ünitede (Kesirlerle İşlemler, Ondalık Gösterim, Yüzdeler), 3. Ünitede (Temel Geometrik Kavramlar ve Çizimler, Üçgenler ve Dörtgenler, Veri İşleme), 4. Ünitede (Uzunluk ve Zaman Ölçme, Alan Ölçme, Geometrik Cisimler) yer verilmiştir. En fazla 1. Ünitede sekiz farklı değere yirmi üç defa değinilirken 4. Ünitede en az olarak iki farklı değere dört defa yer verilmiştir. Kitabın ilk ünitesinde toplamda yer verilen değerlerin yarıdan fazlası yer almaktadır. Buna göre üniteler arası değerlere yer verilme durumunda tutarsızlık olduğu söyleyebilir. Şahin ve Başgül (2018) tarafindan yapılan araştırmada da 5.sınıf matematik ders kitabında değerlerin ünitelere dağılımında tutarsızlı olduğu görülmüştür. Baki (2019) tarafından değerler açısından araştırılan ortaokul Türkçe ders kitaplarında da benzer olarak bazı değerlere az değinilirken bazı değerlere daha çok değinilmiştir. Değerlerin ders kitaplarındaki dağılımının tutarsızlığı bu araştırmalarla uyuşmaktadır.

$\mathrm{Bu}$ araştırmaya göre 5.sınıf matematik ders kitabında en çok yer alan değerler sırasıyla öz denetim, adalet, yardımseverlik ve sorumluluk değeridir. En az değinilen değerler ise dostluk, dürüstlük, vatanseverlik, saygı ve sevgi değerleridir. Sabır değerine ise kitapta değinilmemiştir. Benzer olarak Şahin ve Başgül (2018, s. 95-96) tarafindan yapılan araştırmada 5.sınıf matematik ders kitabında da en fazla değinilen değerlerden bazılarının sorumluluk, evrenselcilik ve yardımlaşma değerleri en az yer verilen değerlerden birinin de saygı değeri olduğu ifade edilmiştir. Fakat Şahin ve Başgül (2018) tarafından yapılan araştırmada kitapta fazlaca değinilen bir değer olarak ifade edilen evrenselcilik değeri araştırmamızda bu başlık altında irdelenmemiştir. Evrenselcilik değerine ait olduğu ifade edilen Rubik Küp ile ilgili motive edici örnek 2018 yılında yayınlanan matematik öğretim programında yer alan sekiz yetkinlikten biri olan kültürel farkındalık ve ifade olarak değerlendirildiğinden bu araştırmada herhangi bir değer altında yer almamıştır. Ayrıca farklı yetkinliklerin değerler olarak ele alınması durumu da söz konusu olabilir. Bu durumdan dolayı bu araştırmada Şahin ve Başgül (2018) tarafindan yapılan araştırmaya göre daha az sayıda değerin yer alması açıklanabilir. Schwartz'ın değer sınıflandırmasında evrenselcilik; anlayış içerisinde, takdir edici ve hoşgörülü olma, insanların ve tabiatın iyiliğini gözetme açık fikirli olmak, erdemli olmak, toplumsal adalet, eşitlik, barış içinde bir dünya istemek, doğayla bütünlük içinde olmak, çevreyi korumak, iç uyumlu olmaktır (Schwartz, 2012, s. 7). Bu ifadeye göre yapılan bu çalışmada bazı değerler evrenselcilik değeri adı altında değil de, kök değerler olarak ifade edilen sevgi, saygı, adalet ve yardımseverlik değerleri adı altında incelenmiştir.

Güzel Candan ve Ergen (2014, s. 153) tarafından yapılan araştırmada 3. sınıf hayat bilgisi kitabında sevgi ve sorumluluk değerlerine daha fazla yer verilirken misafirperverlik ve barış değerlerine daha az yer verildiği ifade edilmiştir. Kuş, Merey ve Karatekin (2013, s. 201-202) tarafindan yapılan araştırmada 4. ve 5. sınıf sosyal bilgiler ders kitaplarında duyarlılık, vatanseverlik, sorumluluk ve sevgi değerleri daha fazla yer alırken temizlik, dürüstlük ve hoşgörü değerlerine daha az yer verildiği ifade edilmiştir. Baki (2019, s. 119-120) tarafindan yapılan araştırmada ortaokul Türkçe ders kitaplarında estetik, nezaket, çalışkanlık ve sevgi değerleri daha fazla yer alırken barış, sadelik, hoşgörü ve alçakgönüllülük değerlerine daha az yer verildiği ifade edilmiştir. Diğer araştırmalarla birlikte bu araştırmaya bakılacak olursa ders kitaplarında daha çok ve daha az değinilen değerler farklılık göstermektedir. Bu farklılıklar ders kitaplarının sınıf seviyelerinden, ders içeriklerinden ve kitabı yazan kişilerin değer algılarından kaynaklanabilir. Ayrıca ders kitaplarında hangi değerlerin yer almasının gerekliliği hususunda ortak bir uzlaşının olmaması da kitaplarda farklı değerlere değinilmesine sebep olabilir.

\section{5. ÖNERILER}

Ders kitaplarında yer alması istenen değerlerde uzlaşı sağlanarak ders kitabı yazan kişilerin bu değerlerden haberdar edilmesi ve bu değerlere yer veren kitapların yazılması sağlanmalıdır. Ortak değerlerin oluşturulması hususunda değerler eğitimi alanında araştırma yapmış uzmanlarla Milli Eğitim Bakanlığı'na bağlı Talim Terbiye Kurulu Başkanlığı kitap inceleme komisyonları birlikte bir çalışma yapabilir. Matematik ders kitapları temel değerler açısından incelenebilir. Ders kitaplarında 
değerlere birbirine yakın sıklıkla yer verilerek değerlerin dağılımında tutarlılık sağlanabilir. Böylece her değere değinilebilir. Ders kitaplarında hangi değerlere vurgu yapılacağı ünite başlarında ifade edilebilir. 5.sınıf matematik ders kitaplarında sevgi, saygı, vatanseverlik, dostluk, dürüstlük ve sabır değerlerine daha fazla değinilebilir.

\section{KAYNAKÇA}

Baki, Y. (2019). Ortaokul Türkçe ders kitaplarındaki metinlerin değer aktarımı açısından incelenmesi. Değerler Eğitimi Dergisi, 17(37), 109-146.

Beil, B. (2003). İyi çocuk, zor çocuk "doğru davranışlar çocuklara nasıl kazandırılır?” (çev. Cuma Yorulmaz). Ankara: Arkadaş Yayınevi.

Bogdan, R. C. ve Biklen, S. K.(1992). Qualitative research for education: An introduction to theory and methods. (2nd ed.). Boston: Allyn \& Bacon.

Cırıtcı, H., Gönen, İ., Kavas, D., Özarslan M., Pekcan, N. ve Şahin, M. (2017). Ortaokul matematik ders kitabr 5. İstanbul: Milli Eğitim Bakanlığı Ders Kitapları.

Çelikkaya, T. ve Kürümlüoğlu, M. (2018). Yenilenen sosyal bilgiler dersi öğretim programına yönelik öğretmen görüşleri. Uluslararası Türk Eğitim Bilimleri Dergisi, 2018(11), 104-120.

Çınar, A. (2013). Değerler felsefesi ve psikolojisi. Bursa: Emin Yayınları.

Dede, Y. (2007). Matematik öğretiminde değerlerin yeri. Abant İzzet Baysal Üniversitesi Eğitim Fakültesi Dergisi, 7(1), 11-19.

Deniz, K. ve Karagöl, E. (2018). Değerler eğitimi açısından ortaokul Türkçe ders kitapları. Karaelmas Ĕ̈itim Bilimleri Dergisi, 6(2), 244-255.

Ekşi, H. (2003). Temel insani değerlerin kazandırılmasında bir yaklaşım: Karakter eğitimi programları. Değerler Ĕ̈itimi Dergisi, 1(1), 79-96.

Elbir, B. ve Bağcı C. (2013). Değerler Eğitimi Üzerine Yapılmış Lisansüstü Düzeyindeki Çalışmaların Değerlendirilmesi. Electronic Turkish Studies, 8(1), 1321-1333.

Güneş, F. (2002). Ders kitaplarının incelenmesi. Ankara: Ocak Yayınları.

Güzel Candan, D. ve Ergen, G. (2014). 3. sınıf hayat bilgisi ders kitaplarının temel evrensel değerleri içermesi bakımından incelenmesi. Uşak Üniversitesi Sosyal Bilimler Dergisi, 7(1), 134-161.

Halstead, J. M. Ve Taylor M.J. (Ed). (1996). Values in education and education in values. Biristol: USA The Falmer Press, Taylor \& Francis Inc.

Kardaş, M. N. ve Cemal, S. (2017). Değerler eğitimi ve Türkçe öğretiminde değer eğitimi üzerine yapılan araştırmalara ilişkin kaynakça denemesi. Karadeniz Sosyal Bilimler Dergisi, 9(16), 383-412.

Keskin, Y. (2008). Türkiye'de sosyal bilgiler öğretim programlarında değerler eğitimi: Tarihsel gelişim, 1998 ve 2004 programlarının etkililiğinin araştırılması. Yayınlanmamış doktora tezi, Marmara Üniversitesi, İstanbul.

Kıncal, R. Y. (2007). Vatandaşlık Bilgisi. (2. Baskı). Ankara: Nobel Yayın Dağıtım.

Kirk, J., Miller, M. L. ve Miller, M. L. (1986). Reliability and validity in qualitative research (Vol. 1). California: Sage Publications.

Kuş, Z., Merey, Z. ve Karatekin, K. (2013). İlköğretim 4. ve 5. sınıf Sosyal Bilgiler ders kitaplarında yer alan değerler. Değerler Eğitimi Dergisi, 11(25), 183-214.

MEB, (2018). Matematik dersi ögretim programı (ilkokul ve ortaokul 1,2,3,4,5, 6, 7 ve 8. sinuflar). 15 Mayıs 2019 tarihinde http://mufredat.meb.gov.tr/ProgramDetay.aspx?PID=329 adresinden erişildi. 
Meydan, H. (2014). Okulda değerler eğitiminin yeri ve değerler eğitimi yaklaşımları üzerine bir değerlendirme. BEÜ Illahiyat Fakültesi Dergisi, 1(1), 93-108.

Miles, M. B. ve Huberman, A. M. (1994). An expanded sourcebook qualitative data analysis. (2nd Edition). California: Sage Publications.

Nelson, M. R. (1987). Children and social studies: Creative teaching in the elementary classroom. California: Harcourt Brace Jovanovich.

Schwartz, S. H. (2012). An overview of the Schwartz theory of basic values. Online readings in Psychology and Culture, 2(1).

Silah, S. (2000). Sosyal Psikoloji. Ankara: Gazi Kitabevi.

Spranger, E. (2001). İnsan Tipleri: Bir kişilik psikolojisi. (çev. Ahmet Aydoğan). İstanbul: İz yayıncilik.

Şahin, Ö. ve Başgül, M. (2018). Ortaokul matematik ders kitaplarında sosyal değerler. Dicle University Journal of Ziya Gokalp Education Faculty, (34), 90-104.

Şahin, T. ve Ersoy, F. (2012). Sosyal bilgiler ders kitaplarının değerler eğitimi yaklaşımları açısından incelenmesi. Kuram ve Uygulamada Eğitim Bilimleri Dergisi, 12(2), 1535-1558.

Şen, Ü. (2007). Milli Eğitim Bakanlığının 2005 yılında tavsiye ettiği 100 temel eser yoluyla Türkçe eğitiminde değerler öğretimi üzerine bir araştırma. Yayımlanmamış yüksek lisans tezi, Gazi Üniversitesi Eğitim Bilimleri Enstitüsü, Ankara.

Özgüven, İ. E. (1999). Psikolojik testler. (3. Bask1). Ankara: PDREM Yayınları.

Tanrı̈ver, H.U. (2003). Ders Kitaplarında Cinsiyet Ayrımcılı̆̆ı. B. Çotuksöken, A. Erzan ve O. Silier (Ed.), Ders Kitaplarında İnsan Hakları Projesi (ss.106-121) içinde. İstanbul: Türkiye Ekonomik ve Toplumsal Tarih Vakfi.

Yaman, E. (2012). Değerler ĕgitimi. Ankara: Akçağ Yayınları.

Yıldırım, A. ve Şimşek, H. (2011). Sosyal bilimlerde nitel araştırma yöntemleri. Ankara: Seçkin Yayınc1lik. 